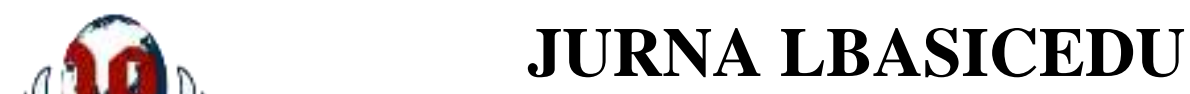

Volume 6 Nomor 1 Tahun 2022 Halaman 797 - 802

Research \& Learningin Elementary Education https://jbasic.org/index.php/basicedu

PAHLATAM

\title{
Pengaruh Model Pembelajaran Inkuiri terhadap Sikap Ilmiah Rasa Ingin Tahu Peserta Didik Sekolah Dasar pada Pembelajaran IPA
}

\author{
Fransiska Faberta Kencana Sari ${ }^{1 凶}$, Stefanus Maranta Lahade ${ }^{2}$ \\ Universitas Negeri Sebelas Maret, Indonesia ${ }^{1}$ \\ Universitas Kristen Satya Wacana, Indonesia ${ }^{2}$

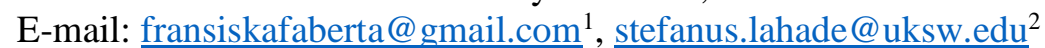

\begin{abstract}
Abstrak
Penelitian ini bertujuan mengetahui pengaruh model pembelajaran Inkuiri terhadap sikap ilmiah rasa ingin tahu peserta didik kelas V pada pembelajaran IPA. Jenis penelitian ini adalah penelitian kuantitatif dengan pendekatan asosiatif. Subjek penelitian adalah peserta didik kelas V di SD N Wiru 01. Pengumpulan data dilakukan menggunakan teknik observasi. Anaisis data dilakukan dengan teknik uji regresi linier yang mencakup uji t dan pengukuran koefisien determinasi. Hasil penelitian menunjukkan 1) Nilai t hitung 2,814 > nilai t tabel 2,160, maknanya terdapat pengaruh model pembelajaran Inkuiri teradap sikap ilmiah rasa ingin tahu peserta didik kelas V pada pembelajaran IPA; 2) Nilai R Square sebesar 0,616, dengan arti bahwa pengaruh variabel model pembelajaran Inkuiri terhadap variabel sikap ilmiah rasa ingin tahu peserta didik kelas V pada pembelajaran IPA adalah 61,6\%. Simpulannya melalui uji t menunjukkan adanya pengaruh model pembelajaran Inkuiri terhadap sikap ilmiah rasa ingin tahu peserta didik kelas $\mathrm{V}$ pada pembelajaran IPA dengan pengaruh sebesar 61,6\% yang ditunjukkan melaui hasil pengukuran koefisien determinasi.
\end{abstract}

Kata Kunci:Model Pembelajaran, Inkuiri, Sikap Ilmiah, Rasa Ingin Tahu, IPA SD.

\begin{abstract}
This study aims to determine the effect of the inquiry learning model on the scientific attitude of curiosity of fifth grade students in science learning. This type of research is quantitative research with an associative approach. The research subjects were fifth grade students at SD N Wiru 01. Data was collected using observation techniques. Data analysis was carried out using a linear regression test technique that included ttest and measurement of the coefficient of determination. The results of the study show 1) The tarithmetic value is 2.814 > the t table value is 2.160, this value implies that there is an influence of the Inquiry learning model on the scientific attitude of curiosity of fifth grade students in science learning; 2) The value of $R$ Square is 0.616, which means that the influence of the Inquiry learning model variable on the scientific attitude variable and the curiosity of fifth grade students in science learning is 61.6\%. The conclusion shown through the t-test is that there is an influence of the Inquiry learning model on the scientific attitude of the curiosity of fifth grade students in science learning, with an effect of $61.6 \%$ which is shown through the measurement results of the coefficient of determination.
\end{abstract}

Keywords: Learning Model, Inquiry, Scientific Attitude, Curiosity, Elementary Science.

Copyright (c) 2022 Fransiska Faberta Kencana Sari, Stefanus Maranta Lahade

$\triangle$ Corresponding author :

Email : fransiskafaberta@gmail.com

DOI : https://doi.org/10.31004/basicedu.v6i1.1973

ISSN 2580-3735 (Media Cetak)

ISSN 2580-1147 (Media Online)

Jurnal Basicedu Vol 6 No 1 Tahun 2022

p-ISSN 2580-3735 e-ISSN 2580-1147 


\section{PENDAHULUAN}

Rasa ingin tahu menjadi salah satu aspek sikap ilmiah yang wajib dimiliki oleh peserta didik. Gruber (2014) memaparkan bahwa penyelidikan ilmiah yang mengeksplor bagaimana rasa ingin tahu (curiosity) akan mempengaruhi ingatan peserta didik karena rasa ingin tahu yang tinggi tidak hanya membuat peserta didik tertarik terhadap informasi yang diberikan tetapi juga tertantang untuk mempelajari informasi tersebut. Indikasinya adalah penting bagi pendidik untuk menstimulus curiosity peserta didik guna menciptakan pembelajaran yang efektif. Faktanya, hasil observasi di SD Wiru 01 Kecamatan Bringin Kabupaten Semarang memperlihatkan bahwa sikap ilmiah rasa ingin tahu yang dimiliki peserta didik kelas $\mathrm{V}$ didominasi pada kategori mulai tampak yaitu sebesar 35\%, diikuti kategori mulai berkembang 33\%, belum tampak sebesar $14 \%$, dan membudaya $0 \%$. Artinya bahwa dibutuhkan model pembelajaran yang mampu memfasilitasi sikap ilmiah rasa ingin tahu peserta didik agar mampu meningkat secara optimal mencapai pada kategori membudaya. Pemerintah (Mendikbud, 2016) menyatakan perlunya penerapan model pembelajaran inovatif seperti inkuiri dalam mengupayakannya. Model pembelajaran berbasis keingintahuan (Inkuiri) menjadi model pembelajaran yang layak untuk dipertimbangkan, karena dalam model ini pembelajaran tidak hanya menekankan perolehan atau penemuan jawaban-jawaban, melainkan juga mendorong keingintahuan peserta didik dalam melakukan penelusuran, pencarian, dan pengembangan kajian serta analisis lebih lanjut (Sari, 2019).

Model pembelajaran inkuiri adalah kerangka konseptual pembelajaran yang melibatkan proses menyelidiki masalah, merumuskan hipotesis, mendesain kegiatan eksperimen, menemukan dan menganalisis data, serta menarik kesimpulan dari masalah tersebut (Wang et al.,2015; Birren \& Kieboom, 2017). Sari (2019) menyatakan sintagmatik model pembelajaran Inkuiri meliputi beberapa tahap diantaranya: a) Mengajukan pertanyaan atau permasalahan; b) Merumuskan hipotesis; c) Mengumpulkan data; d) Menganalisis data; e) Merumuskan kesimpulan. Implikasi dari pelaksanaan model pembelajaran inkuiri memberikan pemahaman peserta didik dengan mengembangkan keterampilan ilmiah mereka (Wheeler et al., 2013; Yudarwati, 2019). Selain itu, model pembelajaran inkuiri secara khusus dapat diterapkan dalam kegiatan eksperimen yang merupakan cara terbaik sebagai pusat pembelajaran dalam mengembangkan kemampuan peserta didik dalam berpikir dan memfasilitasi sikap ilmiah mereka, terutama sikap ingin tahu (Dobber et al., 2017; Veloo et al., 2013).

Sikap ilmiah adalah keyakinan tentang nilai yang harus dipertahankan dalam proses mencari pengetahuan (Giyarti, 2014). Rasa ingin tahu (curiosity) menjadi salah satu dimensi dalam sikap ilmiah sekolah dasar (Bundu, 2006a). Sikap ilmiah rasa ingin tahu peserta didik merupakan bagian penting dari karakter peserta didik yang perlu dikembangkan dalam pembelajaran (Mussel, 2013; Sakaki et al., 2018; Clark et al., 2019). Rasa ingin tahu bisa muncul saat melihat objek atau sejenisnya (Hagtvedt et al., 2019). Jika sikap ingin tahu ini dapat dimanfaatkan dengan baik, maka peserta didik akan semakin memahami berbagai macam konsep dalam fenomena alam (FitzGibbon et al., 2019). Sikap rasa ingin tahu selanjutnya membuat orang lebih sadar akan kebenaran konsep (Baniyamin, \& Rashid, 2016; Mussel, 2013).Zetriuslita (2016)meyatakan rasa ingin tahu adalah sikap ingin mendapatkan jawaban yang benar dari objek yang diamati. Rasa ingin tahu (curiosity) menjadi pendorong peserta didik dalam mencari jawaban terhadap permasalahan yang diberikan. Sikap ingin tahu ditandai dengan minat peserta didik terhadap perilaku alam disekitarnya (Hendracipta, 2016). Sikap ingin tahu selanjutnya mendorong penemuan sesuatu yang baru oleh peserta didik(Bundu, 2006b). Berdasarkan beberapa definisi tersebut sikap ilmiah rasa ingin tahu meliputi beberapa indikator diantaranya: a) Mengajukan pertanyaan tentang objek atau peristiwa; b) Menggunakan beberapa alat indera untuk menyelidiki objek; c) Antusias terhadap proses sains; c) Perhatian pada objek yang diteliti atau diamati; d) Antusias mencari jawaban; dan e) Memperlihatkan minat pada hasil percobaan (Suryani, 2016). Problematika yang muncul adalah keberhasilan peserta didik dalam mencapai sikap ilmiah bersumber dari berbagai faktor 
seperti strategi pembelajaran (model, media bahan ajar), motivasi, keadaan mental ataupun dukungan lingkungan sekitar (Puspitasari, 2020), atau dengan kata lain model pembelajaran bukan satu-satunya faktor yang dapat mempengaruhi sikap ilmiah peserta didik.

Bertolak dari pertimbangan teori serta hasil penelitian sebelumnya diperoleh sebuah hipotesis bahwa model pembelajaran Inkuiri termasuk sebagai faktor yang mempengaruhi sikap ilmiah rasa ingin tahu peserta didik, namun muncul keragu-raguan peneliti diantaranya "apakah sikap ilmiah rasa ingin tahu peserta didik kelas V dalam pembelajaran IPA memang dipengaruhi oleh faktor model pembelajaran Inkuiri?, dan "berapa besar pengaruh model pembelajaran Inkuiri terhadap sikap ilmiah rasa ingin tahu peserta didik kelas V pada pembelajaran IPA?", yang mana menjadi latar belakang dilakukannya penelitian dengan judul "Pengaruh Model Pembelajaran Inkuiri terhadap Sikap Ilmiah Rasa Ingin Tahu Peserta Didik Kelas V Pada Pembelajaran IPA". Adanya fokus penelitian untuk memberikan bukti tingkat pengaruhmodel pembelajaran Inkuiri terhadap sikap ilmiah yaitu rasa ingin tahu peserta didik menjadi kebaharuan penelitian ini dibandingkan dengan beberapa penelitian sebelumnya yang mengkaji sikap ilmiah secara deskriptif (Ulfa, 2018; Hendracipta, 2016). Diharapkan penelitian ini dapat memberikan bukti tingkat pengaruh model pembelajaran Inkuiri terhadap sikap ilmiah rasa ingin tahu peserta didik, sehingga guru dapat mempertimbangkan penerapan model pembelajaran yang tepat bagi peserta didiknya.

\section{METODE}

Penelitian ini menggunakan desain penelitian kuantitatif dengan pendekatan asosiatif. Pendekatan asosiatif dipilih karena penelitian ini bertujuan mencari ada tidaknya pengaruh variabel $\mathrm{x}$ terhadap variabel y, yaitu model pembelajaran Inkuiri terhadap sikap ilmiah rasa ingin tahu peserta didik kelas V dalam pembelajaran IPA. Penelitian ini dilakukan pada semester ganjil tahun ajaran 2021/2022 dengan subjek penelitian adalah 15 peserta didik kelas V di SD N Wiru 01 Kecamatan Bringin Kabupaten Semarang, yang ditentukan sebagai sampel penelitian dengan teknik purposive sampling. Pengumpulan data diperoleh melalui teknik observasi. Data selanjutnya dianalisis dengan teknik uji regresi linier yang meliputi dua tahap yaitu teknik uji $\mathrm{t}$ dan pengukuran koefisien determinasi. Penentuan terdapatnya pengaruh apabila t hitung $>$ dari t tabel, sehingga apabila $t$ hitung $<\mathrm{t}$ tabel maka diperoleh hasil yaitu tidak terdapat pengaruh. Selanjutnya apabila diperoleh hasil terdapat pengaruh, maka tingkat pengaruh diukur berdasarkan nilai R Square yang diperoleh.

\section{HASIL DAN PEMBAHASAN}

Hasil analisis data melalui uji regresi linier dengan teknik uji t dan pengukuran koefisien determinasi diuraikan dalam tabel 1 dan 2 diantaranya:

Tabel 1. Hasil Uji t

\begin{tabular}{|c|c|c|c|c|c|}
\hline Coefficients $^{\mathrm{a}}$ & & & & & \\
\hline \multirow{3}{*}{ Model } & Unstand & arized & Standarized & \multirow{3}{*}{$\mathrm{T}$} & \multirow{3}{*}{ Sig. } \\
\hline & \multicolumn{2}{|c|}{ Coefficients } & Coefficients & & \\
\hline & $\mathrm{B}$ & Std.Error & Beta & & \\
\hline (Constant) & 32,250 & 8,161 & & 4,120 & ,000 \\
\hline Inkuiri & 450 & 220 & ,435 & 2,814 & ,005 \\
\hline \multicolumn{6}{|c|}{ A. Dependent Variable: RASAINGINTAHU } \\
\hline
\end{tabular}


Tabel 2. Hasil Pengukuran Koefisien Determinasi

\begin{tabular}{lllll}
\hline \multicolumn{3}{l}{ Model Summary } & & \\
\hline Model & $\mathrm{R}$ & R Square & $\begin{array}{l}\text { Adjusted } \\
\text { Square }\end{array}$ & $\begin{array}{c}\text { R Std. Error of the } \\
\text { Estimate }\end{array}$ \\
\hline 1 &, $785^{\text {a }}$ &, 616 &, 603 &, 349 \\
\hline \multicolumn{2}{ll}{ a. Predictors: (Constant), MODELPEMBELAJARANINKUIRI } \\
\hline
\end{tabular}

Berdasarkan data tabel 1 diperoleh nilai t hitung 2,814 lebih besar dari nilai t tabel yaitu 2,160, artinya adalah terdapat pengaruh model pembelajaran Inkuiri teradap sikap ilmiah rasa ingin tahu peserta didik kelas V pada pembelajaran IPA. Selanjutnya tabel 2 menunjukkan Nilai R Square sebesar 0,603, yang berarti bahwa pengaruh variabel model pembelajaran Inkuiri terhadap variabel sikap ilmiah rasa ingin tahu peserta didik kelas V pada pembelajaran IPA adalah sebesar $61,6 \%$. Hasil tersebut menjawab hipotesis bahwa memang terdapat pengaruh model pembelajaran Inkuiri terhadap rasa ingin tahu peserta didik kelas $\mathrm{V}$ pada pembelajaran IPA dengan tingkat pengaruh sebesar 61,6\%.

Adanya pengaruh signifikan dari model pembelajaran Inkuiri terhadap sikap ilmiah yaitu rasa ingin tahu peserta didik bersesuaian dengan pernyataan (Dobber et al., 2017; Veloo et al., 2013). bahwa model pembelajaran inkuiri merupakan cara terbaik sebagai pusat pembelajaran dalam mengembangkan kemampuan peserta didik dalam berpikir dan memfasilitasi sikap ilmiah mereka, terutama sikap ingin tahu. Hasil yang diperoleh turut memperkuat fakta bahwa model pembelajaran Inkuiri menjadi model pembelajaran yang layak untuk dipertimbangkan, karena dalam model ini pembelajaran tidak hanya menekankan perolehan atau penemuan jawaban-jawaban, melainkan juga mendorong keingintahuan peserta didik dalam melakukan penelusuran, pencarian, dan pengembangan kajian serta analisis lebih lanjut (Sari, 2019). Model pembelajaran Inkuiri memfasilitasi peserta didik dalam 1) Mengajukan pertanyaan tentang objek atau peristiwa; 2) Menggunakan beberapa alat indera untuk menyelidiki objek; 3) Antusias terhadap proses sains; 4) Perhatian pada objek yang diteliti atau diamati; 5) Antusias mencari jawaban; dan 6) Memperlihatkan minat pada hasil percobaan. Model pembelajaran inkuiri yang mendorog rasa ingin tahu peserta didik membuat peserta didik semakin memahami berbagai macam konsep dalam fenomena alam (FitzGibbon et al., 2019), memfasilitasi peserta didik dalam mencari jawaban terhadap permasalahan yang diberikan (Hendracipta, 2016), serta membuat peserta didik lebih sadar akan kebenaran konsep (Baniyamin, \& Rashid, 2016; Mussel, 2013). Agar pengaruh terhadap sikap ilmiah rasa ingin tahu peserta didik dapat terjadi secara optimal guru perlu menerapkan setiap sintaks dalam model pembelajaran Inkuiri yang meliputi a) Mengajukan pertanyaan/permasalahan; b) Merumuskan hipotesis; c) Mengumpulkan data; d) Menganalisis data; dan e) Merumuskan kesimpulan secara efektif dan sistematis (Sari, 2019).

Terdapatnya pengaruh model pembelajaran Inkuri terhadap sikap ilmiah sejalan dengan hasil penelitian sebelumnya Hendracipta (2016) bahwa model pembelajaran Inkuiri dapat menumbuhkan sikap ilmiah peserta didik pada pembelajaran IPA. Model pembelajaran Inkuiri sebagai model yang tepat dalam membudayakan sikap ilmiah peserta didik (Veloo et al., 2013). Tingkat pengaruh yang diperoleh adalah $61,6 \%$, artinya 38,4 $\%$ merupakan faktor lain yang turut mempengaruhi sikap ilmiah rasa ingin tahu peserta didik pada pembelajaran IPA. Belum diketahuinya faktor lain tersebut menjadi keterbatasan dalam penelitian ini. Sebagaimana dinyatakan Puspitasari (2020), faktor-faktor yang mempengaruhi keberhasilan peserta didik dalam mencapai sikap ilmiah bersumber dari berbagai faktor seperti strategi pembelajaran (model, media bahan ajar), motivasi, keadaan mental ataupun dukungan lingkungan sekitar, sehingga perlu dikaji lebih menyeluruh lagi atas apa yang menjadi pengaruh dalam mengoptimalkan sikap ilmiah rasa ingin tahu peserta didik secara kontekstual selain model pembelajaran. 


\section{KESIMPULAN}

Melalui uji t diperoleh nilai t hitung adalah 2,814 yang lebih besar dari nilai t tabel yaitu 2,160, hasil tersebut menunjukkan makna bahwa adanya pengaruh model pembelajaran Inkuiri teradap sikap ilmiah rasa ingin tahu peserta didik kelas V pada pembelajaran IPA, dengan pengaruh sebesar $61,6 \%$ yang ditunjukkan melaui hasil pengukuran koefisien determinasi.Hasil yang diperoleh memperkuat fakta bahwa model pembelajaran Inkuiri menjadi model pembelajaran yang layak untuk dipertimbangkan, karena dalam model ini pembelajaran tidak hanya menekankan perolehan atau penemuan jawaban-jawaban, melainkan juga mendorong keingintahuan peserta didik dalam melakukan penelusuran, pencarian, dan pengembangan kajian serta analisis lebih lanjut. Model pembelajaran Inkuiri memfasilitasi peserta didik dalam 1) Mengajukan pertanyaan tentang objek atau peristiwa; 2) Menggunakan beberapa alat indera untuk menyelidiki objek; 3) Antusias terhadap proses sains; 4) Perhatian pada objek yang diteliti atau diamati; 5) Antusias mencari jawaban; dan 6) Memperlihatkan minat pada hasil percobaan, yang bermuara pada rasa ingin tahu peserta peserta didik untuk semakin memahami berbagai macam konsep dalam fenomena alam.

\section{DAFTAR PUSTAKA}

Baniyamin, N., \& Rashid, M. M. (2016). Understanding Science Centre Engagement In Nurturing Visitor Interest And Curiosity. Procedia - Social And Behavioral Sciences, 222(4), 235-243.

Birren, \& K. (2017). Exploring The Development Of Core Teaching Practices In The Context Of Inquiry-Based Science Instruction: An Interpretive Case Study. Teaching And Teacher Education, 66(8), 74-87.

Bundu, P. (2006a). Model Keterampilan Proses Dan Sikap Ilmiah Dalam Pembelajaran Sains SD. Jakarta: Depdiknas.

Bundu, P. (2006b). Penilaian Keterampilan Proses Dan Sikap Ilmiah. Jakarta: Depdiknas.

Clark, S., Harbaugh, A. G., \& Seider, S. (2019). Fostering Adolescent Curiosity Through A Question Brainstorming Intervention. Journal Of Adolescence, 75(4), 98-112.

Dobber, M., Zwart., Tanis, M., \& V. O. (2017). Literature Review: The Role Of The Teacher In Inquiry-Based Education. Educational Research Review, 22(2), 194-214.

Fitzgibbon, L., Moll, H., Carboni, J., Lee, R., \& Dehghani, M. (2019). Counterfactual Curiosity In Preschool Children. Journal Of Experimental Child Psychology, 186(2), 146-157.

Giyarti. (2014). Peningkatan Keterampilan Proses Dan Hasil Belajar IPA. Pendidikan Sains, 8(1), 24-30.

Gruber. (2014). States Of Curiosity Modulate Hippocampus-Dependent Learning Via The Dopaminergic Circuit. Neuron Journal, 84(2), 486-496.

Hagtvedt, L. P., Dossinger, K., Harrison, S. H., \& Huang, L. (2019). Curiosity Made The Cat More Creative: Specific Curiosity As A Driver Of Creativity. Organizational Behavior And Human Decision Processes, 150(3), 1-13.

Hendracipta, N. (2016). Menumbuhkan Sikap Ilmiah Siswa Sekolah Dasar Melalui Pembelajaran IPA Berbasis Inkuiri. Jurnal Pendidikan Sekolah Dasar, 2(1), 109-116.

Mendikbud. (2016). Standar Proses Pendidikan Dasar Dan Menengah. In Permendikbud (Vol. 3, Issue 2).

Mussel, P. (2013). Introducing The Construct Curiosity For Predicting Job Performance. Journal Of 
Organizational Behavior, 34(4), 453-472.

Puspitasari. (2020). Faktor Yang Mempengaruhi Prestasi Belajar Peserta Didik Sekolah Dasar. Pandawa, 3(2), 32-40.

Sakaki., Yagi, A., \& M. (2018). Curiosity In Old Age: A Possible Key To Achieving Adaptive Aging. Neuroscience And Biobehavioral Reviews, 88(2), 106-116.

Sari, F. F. K. (2019). Keefektifan Model Pembelajaran Inquiry Dan Discovery Learning Bermuatan Karakter Terhadap Keterampilan Proses Ilmiah Siswa Kelas V Dalam Pembelajaran Tematik. 1-7. Https://Doi.Org/Https://Doi.Org/10.11591/Ijere.V9i1.20422

Suryani, I. (2016). Pengembangan Instrumen Penilaian Sikap Ilmiah Pada Pembelajaran Dengan Model Latihan Penelitian Di Sekolah Dasar. PEDADIDAKTIKA: Jurnal Ilmiah Pendidikan Guru Sekolah Dasar, 3(2), 217-227.

ULFA, S. W. (2018). Mentradisikan Sikap Ilmiah Dalam Pembelajaran Biologi.1(1), 1-10.

Veloo, A., Perumal, S., \& Vikneswary, R. (2013). Inquiry-Based Instruction, Students' Attitudes \& Teachers' Support Towards Science Achievement In Rural Primary Schools. Procedia - Social And Behavioral Sciences, 93(3), 65-69.

Wang., Wu., \& Lin, Y. (2015). Influence Of Implementing Inquiry-Based Instruction On Science Learning Motivation And Interest: A Perspective Of Comparison. Procedia - Social And Behavioral Sciences, 174(11), 1292-1299.

Wheeler, L. B., Maeng, J. L., \& Whitworth, B. A. (2013). Understanding And Structuring Inquiry: A Tale Of Three Teachers. In NARST 2013 Annual International Conference, 26(2), 78-85.

Yudarwati. (2019). Appreciative Inquiry For Community Engagement In Indonesia Rural Communities. Public Relations Review, 45(4), 1-14.

Zetriuslita. (2016). Profil Sikap Ilmiah Rasa Ingin Tahu (Curiosity) Matematis Siswa. Jurnal Ilmu Pendidikan, 8(1), 41-46. 